\title{
Schreibweise antiker Namen
}

Griechische Namen werden i.a. philologisch korrekt transkribiert (also Nestorios statt Nestorius), lateinische Namen, die in griechischen Quellen zitiert werden, allerdings in lateinischer Form und umgekehrt. Bei sehr bekannten Namen (Eusebius, Basilius usw.) habe ich auf die im Deutschen geläufige lateinische Form zurückgegriffen. 
